\title{
SEASONAL CHANGES AND TOXIC POTENCY OF LANDFILL LEACHATE FOR WHITE MUSTARD (SINAPIS ALBAL.)
}

\author{
Jan Zlochํ, Magdalena Daria Vaverkován , Dana Adamcován , Maja Radziemska², \\ Tomáš Vyhnánek ${ }^{1}$, Václav Trojan ${ }^{1}$, Biljana Đorđevićc ${ }^{1}$, Martin Brtnický ${ }^{3}$

\begin{abstract}
${ }^{1}$ Department of Applied and Landscape Ecology, Faculty of AgriSciences, Mendel University in Brno, Zemědělská 1, 61300 Brno, Czech Republic

${ }^{2}$ Department of Environmental Improvement, Faculty of Civil and Environmental Engineering, Warsaw University of Life Sciences - SGGW, Nowoursynowska 159, Warsaw, Poland

${ }^{3}$ Department of Geology and Pedology, Faculty of Forestry and Wood Technology, Mendel University in Brno, Zemědělská 1, 61300 Brno 13, Czech Republic
\end{abstract}

\begin{abstract}
ZLOCH JAN, VAVERKOVÁ MAGDALENA DARIA, ADAMCOVÁ DANA, RADZIEMSKA MAJA, VYHNÁNEK TOMÁŠ, TROJAN1 VÁCLAV, ĐORĐEVIĆ BILJANA, BRTNICKÝ MARTIN. 2018. Seasonal Changes and Toxic Potency of Landfill Leachate for White Mustard (Sinapis Alba L.). Acta Universitatis Agriculturae et Silviculturae Mendelianae Brunensis, 66(1): 235-242.

Landfills are the most broadly used methods for the disposal of municipal solid waste (MSW). Leachate can be contaminated with pollutants that may pose a threat to the landfill surrounding namely soil, groundwater and surface waters.. Examination of leachate composition is determinative in long-term impact of landfills on the environment and human health. Moreover, it is essential to assess such prior knowledge for prevention of negative outcomes. The evaluation of the seasonal changes of landfill leachate and rainwater composition is presented in this paper. Research samples of leachate and rainwater were collected from February till June of 2017 (still ongoing) and analyzed for $\mathrm{pH}$, electrical conductivity, dissolved oxygen, series of trace elements, Subsequently the test of leachate toxicity for higher plants (Sinapis alba L.) was carried out. Up to now, the results do not indicate significant seasonal difference in landfill leachate composition, however the toxicity tests provided on Sinapis alba L. demonstrate that landfill leachates can present a significant source of contamination. This research can serve practical tools for evaluating quality and risk assessment for landfill leachate.
\end{abstract}

Keywords: waste, landfill, toxicity tests, pollution, Sinapis alba L.

\section{INTRODUCTION}

The oldest form of the removal and disposal of waste is landfilling (Vaverková et al., 2013; Vaverková and Adamcová 2014; Koda et al., 2015; Adamcová et al., 2016a; Ghosh et al., 2017) and landfills are broadly used methods for the disposal of MSW (Baderna et al., 2011; Tsarpali et al., 2012). Moreover, in the future, landfill will continue to be a major disposal option for MSW. This method of waste disposal are known source of environmental pollution (Hu et al., 2017), and waste buried in landfill is subjected to a series of physico-chemical and biological transformations, generating potentially polluted water-leachate (Ghosh et al., 2017). Leachate may contaminate the groundwater as well as the surface waters (Gworek et. al., 2015; Li et al., 2017). The composition of leachate is affected significantly by the type of landfill, the waste disposed, the degree of compaction, and water content (Koda et al., 2015; Zhao et al., 2017). It is defined by high concentrations of organic and inorganic compounds, derived mainly from the disposal of non-hazardous MSW, as well as toxic chemicals (Tsarpali et al., 2012). If a waste has a high content of organic fraction, leachate is characterized by a higher oxygen content and higher 
concentration of ammonium and organic nitrogen (Koda et al., 2015). Generally, leachate from MSW landfill sites has the same composition: Chemical Oxygen Demand (COD), Total Organic Carbon (TOC), volatile fatty, inorganic macro components like $\mathrm{Ca}^{2+}, \mathrm{Mg}^{2+}, \mathrm{Na}^{+}, \mathrm{K}^{+}, \mathrm{NH}_{4}^{+}, \mathrm{Cl}^{-}, \mathrm{SO}_{4}^{2-}, \mathrm{HCO}_{3}^{-}$, trace elements and xenobiotic organic compounds (Ghosh et al., 2017). But trace elements are the most toxic and/or problematic pollutants in leachate. Authors (Baun and Christensen 2004; Öman and Junestedt 2008; Renou et al., 2008), suggested that typical trace elements concentrations in leachate are: $\mathrm{Cd}$ (0.0001-0.13 mg/L), Cr (0.0005-1.6 mg/L), Fe (0.08-2,100 mg/L), Mn (0.01-65 mg/L), Ni (0.03$3.2 \mathrm{mg} / \mathrm{L}), \mathrm{Pb}(0.0005-1.5 \mathrm{mg} / \mathrm{L})$, and $\mathrm{Zn}(0.00005-$ $120 \mathrm{mg} / \mathrm{L})$. The trace elements concentrations in young (acetogenic) leachate are usually higher than those in old (methanogenic) leachate (Kjeldsen et al., 2002; Öman and Junestedt 2008; Oka et al., 2017).

Commonly, assessment of leachate is based on identification of pollutants through chemical analyses (Ghosh et al., 2017), however, evaluation of leachate can be based also on the interactions with biota (Kjeldsen et al., 2002, Tsarpali et al., 2012). Actually, chemical analysis gives results about landfill leachate composition/pollution, while the toxicological tests, integrates the effect of all contaminants, providing information on their bioavailable fraction (Pandard et al., 2006; Kalcikova et al., 2011; Tsarpali et al., 2012).

From the literature view it can be concluded that papers usually contain only random leachate characterization (Wu et al., 2004; Bila et al., 2005; Kurniawan et al., 2006; Laitinen et al., 2006, Gworek et. al., 2015), however, toxicological evaluation of leachate to examine the impact of leachate discharged into the environment is rather rare. Only some authors have tried to characterize leachate composition during the landfill exploitation. Therefore, the purpose of this study was to characterize the major components of leachate from MSW landfill, namely the landfill site in ZdounkyKuchyňky (Czech Republic). To authors best knowledge, the seasonally variety of leachate is not well studied yet.

An experimental investigation was conducted to explore: (a) the trace elements concentrations in leachate, (b) the phytotoxicity of the leachate, (c) the effects of leachate on root growth inhibition of Sinapis alba L. and, (d) the seasonal alterations of leachate toxicity. Additionally, rainwater characterization was also defined. Moreover, this study is a part of the long-term research of landfill Zdounky-Kuchyňky and its influence on the environment.

\section{MATERIALS AND METHODS}

\section{Landfill site description}

The Zdounky-Kuchyňky landfill (49.2490778 N, 17.3121181 E) (Fig. 1) is an active and sanitary (with leachate protective layer) landfill site located in the Czech Republic (CR). The landfill activity started in 1995. It is situated in a triangular space delimited by main roads connecting the villages of Zdounky, Nětčice and Troubky-Zdislavice (Vaverková et. al., 2012). The designed area of the landfill is $70,700 \mathrm{~m}^{2}$ with a total volume of $907,000 \mathrm{~m}^{3}$, i.e. ca. $1,000,00010^{3} \mathrm{~kg}$ of waste. The planned service life of the facility is up to 2027. The landfill receives waste from a catchment area with a population of around 75,000 residents. The annually deposited amount of waste is around $40,000 \cdot 10^{3} \mathrm{~kg}$ (50\% is from the communal sphere, non-hazardous waste including MSW). The surrounding is bordered by agricultural fields. The leachate is collected via a draining system and stored in leachate pond (receiving system) (Vaverková et.al., 2012).

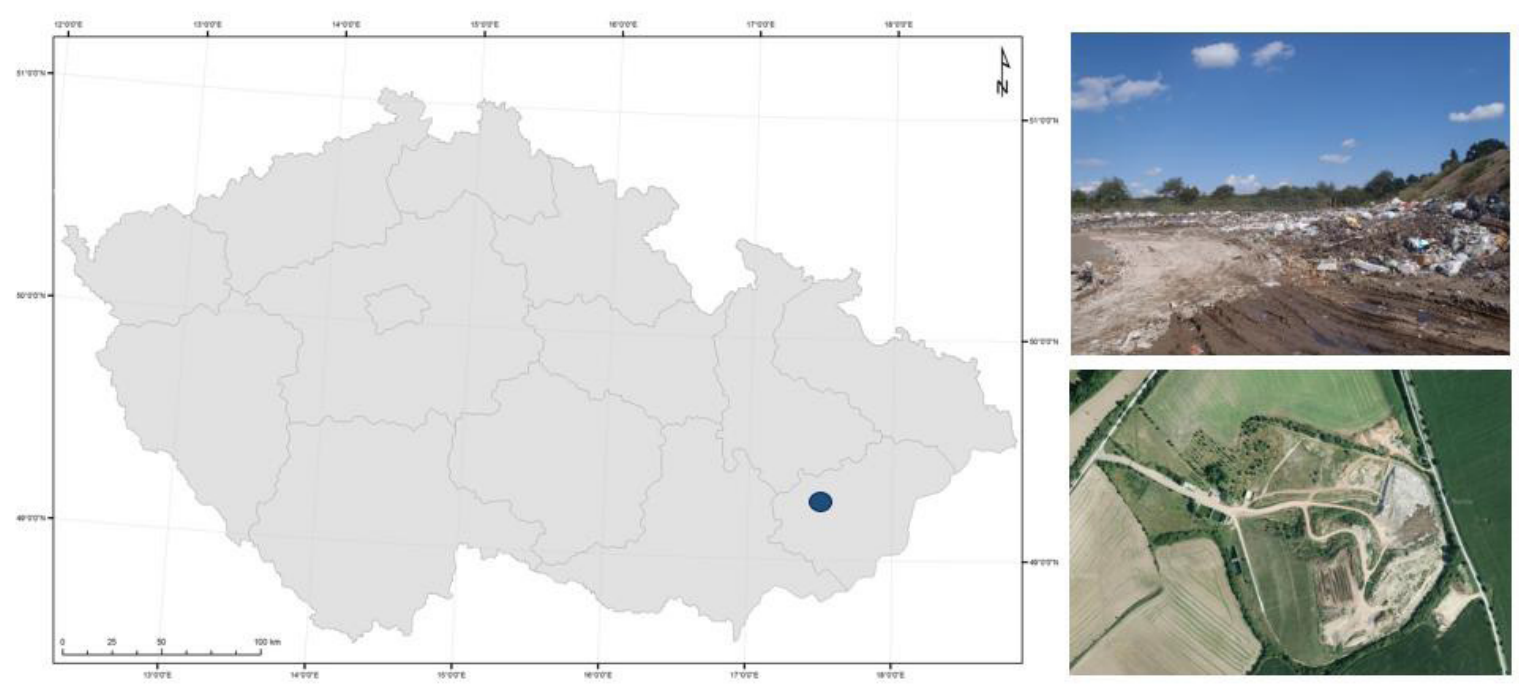

1: Map of the case-study landfill Zdounky-Kuchyňky (adapted from Google Maps Data). 


\section{Leachate sampling}

Leachate and rainwater samples were collected from February till June of 2017 (still ongoing). The sample of the leachate and rainwater were not collected in January (2017) because the ponds were frozen. The frequency of leachate and rainwater sampling from leachate pond and rainwater pond was one time per month. Two samples (0.5 L/sample) of leachate (leachate pond) and rainwater (rainwater pond) (Fig. 2) were collected in sterile collection containers. Samples were stored at $4{ }^{\circ} \mathrm{C}$ and transported to the analytical laboratory at the Department of Chemistry and Biochemistry, Faculty of AgriSciences, Mendel University in Brno for analysis within $72 \mathrm{~h}$. Leachate and rainwater samples were analyzed for $\mathrm{pH}$, electrical conductivity (EC), chemical oxygen demand (COD) in situ using a Multi-Parameter Meter HQ30d Portable and series of analyses of trace elements (Cd, Cr, Ni, Pb, Zn, Hg) ex situ.

\section{Phytotoxicity test}

White mustard (Sinapis alba L.) was used as a test organism to assess toxicity of leachate and rainwater samples. Sinapis alba L. is ideal for studying toxicity because it is sensitive to board range of chemicals. The effect of toxicity was assessed based on physiological (germination energy and germination) and morphological traits (root length) of white mustard (Sinapis alba L.). The treatments consisted of different concentrations of $25 \%, 50 \%, 75 \%$ and $90 \%$ (three replicate samples). Concentrations of leachate and rainwater has been chosen on the basis of authors previous experiments and studies (Vaverková et al., 2017). The test organisms were germinated in petri dishes and exposed to the leachate and rainwater solutions for a total of $72 \mathrm{~h}$. The hydroponic solution (distilled water with the following chemical ingredients (mg/L): $\quad \mathrm{Ca}\left(\mathrm{NO}_{3}\right)_{2} \mathrm{O} .8, \quad \mathrm{KH}_{2} \mathrm{PO}_{4} \mathrm{0.2}, \quad \mathrm{KNO}_{3} 0.2$, $\mathrm{MgSO}_{4} .7 \mathrm{H}_{2} \mathrm{O} 0.2, \quad \mathrm{KCl} 0.2, \quad \mathrm{FeSO}_{4} 0.01, \quad \mathrm{pH}=5.2$ ) with tested liquid was added into each dish, and 15 healthy looking seeds of similar size were evenly spread onto the surface of the filter paper. The petri dishes were covered by a glass cap to prevent loss due to evaporation and were located in the EcoCell thermostat $\left(\mathrm{t}=24^{\circ} \mathrm{C}\right.$, air humidity $80 \%$, dark environment). The root length were recorded at the end of the 3rd day (Fargašová 2004; Adamcová et al., 2016b; Vaverková et al., 2017).

\section{Calculations and Data analysis}

The analyses and the length measurements were performed using the Image Tool 3.0 for Windows (UTHSCSA, San Antonio, USA). The percent of root growth inhibition (RI) were calculated with the formula (Eq. 1):

$\mathrm{RI}=\mathrm{A}-\mathrm{B} / \mathrm{A} \times 100$

Where: A means root length in the control; B means root length in the test (Adamcová et al., 2016b).

\section{RESULTS AND DISCUSSION}

\section{Chemical characteristics of landfill leachate and rainwater}

Chemical characteristics of leachate are summarized in Tab. I and Tab. II. Investigated landfill leachates showed similar characteristics to the leachates sampled in other MSW landfills (Kulikowska and Klimiuk 2008; Guo et al., 2010; Kalčíková et al., 2014). The pH of leachate was 8.03 and demonstrated that the leachate was alkaline and that the landfill is already in methanogenic phase of life cycle. It can be concluded that most of the chemical substance in the leachate is basic
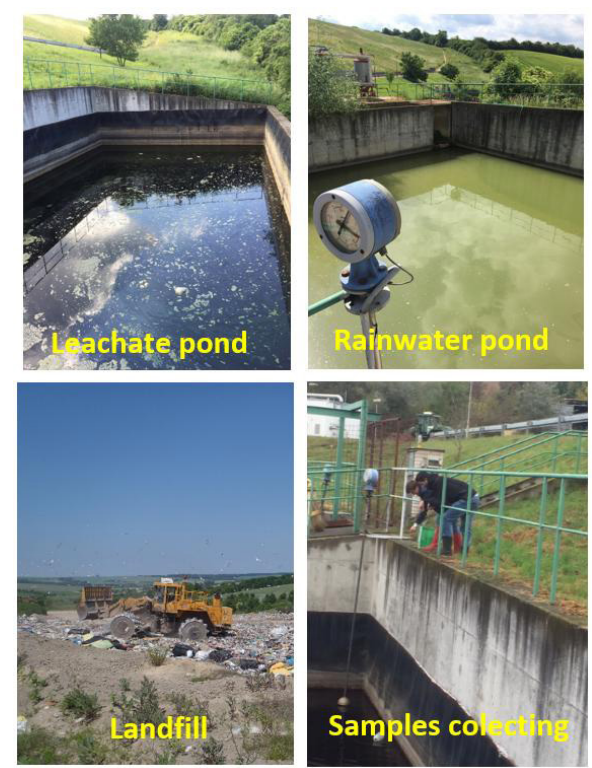

2: Leachate pond and rainwater pond. 
I: Trace elements concentrations in leachate

\begin{tabular}{lcccccccc}
\hline \multicolumn{1}{c}{ Leachate } & Trace element & $\mathbf{C d}$ & $\mathbf{P b}$ & $\mathbf{A s}$ & $\mathbf{C r}$ & $\mathbf{N i}$ & $\mathbf{Z n}$ & $\mathbf{H g}$ \\
\hline \multicolumn{1}{c}{ Month } & Unit & $\boldsymbol{\mu g} / \mathbf{L}$ & $\boldsymbol{\mu g} / \mathbf{L}$ & $\boldsymbol{\mu g} / \mathbf{L}$ & $\boldsymbol{\mu g} / \mathbf{L}$ & $\boldsymbol{\mu g} / \mathbf{L}$ & $\boldsymbol{\mu g} / \mathbf{L}$ & $\boldsymbol{\mu g} / \mathbf{L}$ \\
\hline February & Concentration & 0.179 & 11.32 & 12.54 & 74.33 & 34.84 & 0.0652 & 0.00306 \\
March & SD\% & 33.5 & 0.6 & 0.7 & 1.3 & 2.8 & 4.1 & 0.164 \\
& Concentration & 0.373 & 3.299 & 11.55 & 59.3 & 70.29 & 0.0251 & 0.00045 \\
April & SD $\%$ & 24.7 & 24.5 & 1.1 & 27.8 & 13.9 & 8.3 & 0.001 \\
& Concentration & 0.237 & 6.448 & 17.56 & 442.68 & 135 & 0.0787 & 0.0023 \\
May & SD $\%$ & 26.1 & 6.3 & 14.2 & 30.7 & 11.6 & 1.3 & 0.048 \\
& Concentration & 0.518 & 15.262 & 4.5 & 108.19 & 155 & 0.4723 & 0.00393 \\
June & SD\% & 33.1 & 5.4 & 28.2 & 20.6 & 5.7 & 0.7 & 0.005 \\
& Concentration & $<$ LOD & 5.282 & 35.91 & 325.72 & 139.22 & 52.6 & 0.64 \\
\hline
\end{tabular}

*Standard deviation (SD)

**Limit of detections (LOD)

II: Main chemical properties of the leachate

\begin{tabular}{lccccc}
\hline \multicolumn{1}{c}{ Parameters } & February & March & April & May & June \\
\hline COD $(\mathbf{m g} / \mathbf{L})$ & 2.38 & 0.99 & 1.69 & 0.13 & 2.92 \\
pH & 7.35 & 7.6 & 7.92 & 8.7 & 8.61 \\
EC $(\boldsymbol{\mu S} / \mathbf{c m})$ & 2.65 & 6.12 & 12.79 & 10.87 & 11.69 \\
\hline
\end{tabular}

*Chemical oxygen demand (COD)

**Electrical conductivity (EC)

III: Trace elements concentrations in rainwater

\begin{tabular}{|c|c|c|c|c|c|c|c|c|}
\hline Rainwater & Trace element & Cd & $\mathbf{P b}$ & As & $\mathrm{Cr}$ & $\mathbf{N i}$ & $\mathrm{Zn}$ & $\mathrm{Hg}$ \\
\hline Month & Unit & $\mu \mathrm{g} / \mathrm{L}$ & $\mu \mathrm{g} / \mathrm{L}$ & $\mu \mathrm{g} / \mathrm{L}$ & $\mu \mathrm{g} / \mathrm{L}$ & $\mu g / L$ & $\mu g / L$ & $\mu \mathrm{g} / \mathrm{L}$ \\
\hline \multirow[t]{2}{*}{ February } & Concentration & $<\mathrm{LOD}$ & 6.57 & $<\mathrm{LOD}$ & 8.48 & 2.18 & 0.033 & 0.00056 \\
\hline & $\mathrm{SD} \%$ & & 0.7 & & 25.4 & 0.7 & 11.9 & 0.018 \\
\hline \multirow[t]{2}{*}{ March } & Concentration & $<\mathrm{LOD}$ & 1.766 & $<\mathrm{LOD}$ & 5.45 & 9.88 & 0.011 & 0.00057 \\
\hline & $\mathrm{SD} \%$ & & 27.9 & & 5.9 & 6.1 & 7 & 0.002 \\
\hline \multirow[t]{2}{*}{ April } & Concentration & $<\mathrm{LOD}$ & 2.591 & 1.16 & $<\mathrm{LOD}$ & 2.7 & 0.0165 & 0.00133 \\
\hline & SD\% & & 18.7 & 1.3 & & 31.1 & 4 & 0.02 \\
\hline \multirow[t]{2}{*}{ May } & Concentration & $<\mathrm{LOD}$ & 2.091 & 0.74 & 1.06 & 5.73 & 0.0091 & 0.00203 \\
\hline & $\mathrm{SD} \%$ & & 0.8 & 21.4 & 22.9 & 25.8 & 5.9 & 0.004 \\
\hline \multirow[t]{2}{*}{ June } & Concentration & $<\mathrm{LOD}$ & $<\mathrm{LOD}$ & 1.18 & 9.75 & 4.37 & 10.7 & 0.93 \\
\hline & $\mathrm{SD} \%$ & & & 4.8 & 4.8 & 8.3 & 3.9 & 0.001 \\
\hline
\end{tabular}

*Standard deviation (SD)

** Limit of detection (LOD)

IV: Main chemical properties of the landfill rainwater

\begin{tabular}{lccccc}
\hline \multicolumn{1}{c}{ Parameters } & February & March & April & May & June \\
\hline COD $(\mathbf{m g} / \mathbf{L})$ & 10.16 & 9.37 & 10.02 & 8.56 & 9.18 \\
pH & 8.65 & 7.71 & 7.99 & 7.97 & 7.9 \\
EC $(\boldsymbol{\mu S} / \mathbf{c m})$ & 1281 & 1244 & 1217 & 1181 & 1209 \\
\hline
\end{tabular}

*Chemical oxygen demand (COD)

**Electrical conductivity (EC) 
in nature. The pH of Zdounky-Kuchyňky leachate was in agreement with other sanitary landfills for example in with Jeram's landfill Malaysia; Ampar Tenang, Malaysia; Rio de Janeiro, Brazil and Casone, Italy in which the $\mathrm{pH}$ fell within the range of 7.36-8.80 (Isidori et al., 2003; Silva et al., 2004; Alkassasbeh et al., 2009; Budi et al., 2016).

Relatively low trace elements concentrations are suggesting that Zdounky-Kuchyňky leachate does not represent a significant trace elements hazard. These low values of trace elements in leachate were in agreement with sanitary landfills in Sweden and Brazil (Silva et al., 2004; Öman and Junestedt 2008).

The concentration of $\mathrm{Hg}$ and $\mathrm{Pb}$ over a given period of leachate samples was stable, with an increase in concentrations of trace elements As, $\mathrm{Cr}, \mathrm{Ni}, \mathrm{Zn}$ and $\mathrm{Hg}$. The highest concentrations were recorded for trace elements: $\mathrm{Cr}, \mathrm{Ni}$ and $\mathrm{Zn}$. The lowest concentrations were recorded for $\mathrm{Cd}$, $\mathrm{Pb}$ and As.

It can bee concluded that with the passage of time and with seasonal changes values of various parameters (trace elements) in leachate increased, the main reason is that the solid waste material degraded with time and the waste constituents percolated down along with rainwater. Moreover, the age and seasonal changes (like precipitation) has an important effect on leachate composition. However, it was observed that trace elements concentration in rainwater in time decreased. Chemical characteristics of Zdounky-Kuchyňky rainwater are summarized in Tab. III and Tab. IV.

The concentration of $\mathrm{Cd}, \mathrm{Pb}, \mathrm{As}, \mathrm{Cr}, \mathrm{Ni}$, and $\mathrm{Hg}$ over a given period for rainwater samples was constant, with a significant decrease in the concentration of Zn. However, the concentration of $\mathrm{Zn}$ was the highest.

\section{Plant growth inhibition}

The germination of crop plants was tested using the hydroponics medium supplemented with leachate and rainwater 25\%, 50\%, 75\%, 90\% and $100 \%$. The number of germinated seeds was compared with the control. Results are expressed as
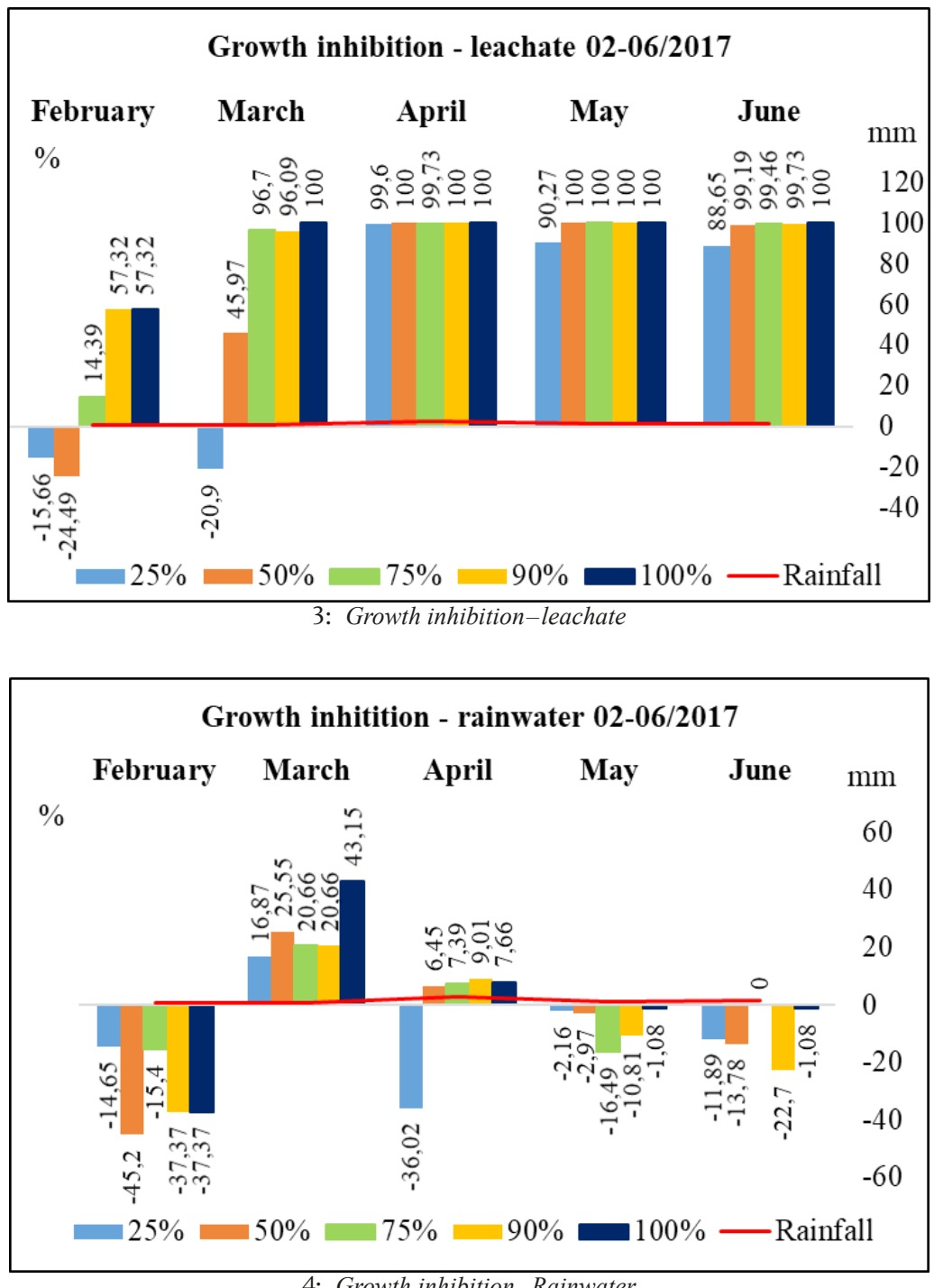

4: Growth inhibition-Rainwater 
mean \pm standard deviation (SD). The average rainfall for the given period was $89.72 \mathrm{~mm}$ (February-June).

The image of the growth inhibitions of Sinapis alba L. leachate samples for months February, March, April, May, June (concentration 25\%, 50\%, 75\%, $90 \%$ and $100 \%$ ) are shown on Fig. 3. Leachate samples for those months were toxic. The growth inhibition values for sample February ranged from - $24.49 \%$ to $57.32 \%$, which is the lowest growth inhibition of all tested samples. The results reveal that the growth inhibition for sample March, April, May, June (concentration 25\%, 50\%, 75\%, 90\% and 100\%) were toxic likewise (average value $89.72 \%$ ). With increasing leachate concentrations, the examined samples showed higher values of growth inhibition. These results provide reference data for risk assessment and the management of leachate.

Leachate may contain a wide range of inorganic, natural and xenobiotic compounds, the mixture of which can affects the plant growth (Zhang et al., 2013 It was found that leachate at higher levels (concentrations) can severely inhibit plant growth, whereas leachate at lower levels (concentration 25\%) can stimulate growth. It is reported that leachate at high levels could lead to a yield reduction and poor survival rate (Menser, 1981; Menser et al., 1983); however, the leachate at low levels (concentrations) enhanced the growth, survival and stomatal conductance of plants (Liang et al., 1999; Sang and Li 2004; Sang et al., 2006; Li et al., 2008; Zhang et al., 2013).

The image of the growth inhibitions of Sinapis alba L. rainwater samples for months February, March, April, May, June (concentration 25\%, 50\%, $75 \%, 90 \%$ and $100 \%$ ) are show on Fig. 4. The results show that the growth inhibition (\%) for rainwater samples-February, April, May, June (concentration $25 \%, 50 \%, 75 \%, 90 \%$ and $100 \%$ ) compared to leachate were not toxic. The growth inhibition values for sample March ranged from $16.87 \%$ to $43.15 \%$, which is the highest growth inhibition of all tested samples. The growth inhibition values for sample February ranged from $-14.65 \%$ to $-45.2 \%$, which is the lowest growth inhibition of all tested samples.

It is worth to mention that previous studies have confirmed that bioassays eliminate the limitations of classical chemical analyses (Ghosh et al., 2017) and that higher plants might be helpful for screening and monitoring of environmental contaminants.

Experimental studies on the phytotoxicity of leachate have reported both positive and detrimental effects on plants (Zhang et al., 2013). The toxicity of leachate was investigated by a numerical study. Bortolotto et al. (2009) evaluated Southern Brazil landfill leachates toxicity using A.cepa as an indicator species. In this study the untreated leachate resulted in a significant inhibition of root growth, whereas the treated leachate did not showed a significant toxicity.. Authors concluded that the leachate treatment caused the reduction in toxicity observed in Artemia sp. toxicity assays (Bortolotto et al. 2009).

Results of the present toxicological assessment of leachates showed that their quality are inconsequential during the study period (FebruaryJune 2017). However, interestingly, this is contrary to a study conducted by Sang and Li (2004). They reported that leachate toxicity varies seasonally while working with Vicia faba as a model test organism. In this study authors observed severe genetic damages in V. faba in case of leachate depending on the season (cold and dry season compared to the the hot and rainy season) owing to seasonal changes in the concentrations of contaminants in the leachates (Sang and Li 2004).

\section{CONCLUSION}

The current study contributes to our knowledge about chemical parameters, toxicity and/or pollution of leachate during various seasons of the year to achieve an appropriate assessment of its environmental impact. It can be concluded that with the passage of time values of trace elements in landfill leachate increased. However, trace elements concentration in rainwater in time decreased. Furthermore, results of the present toxicological assessment of leachate showed no significant changes in leachate toxicity during the study period (February-June 2017). The second major finding was that leachate at higher levels (concentrations) can heavily inhibit plant growth, whereas leachate at lower levels (concentrations) can stimulate growth. Based on the results it is recommended that further research be undertaken in the evaluation in leachate toxicity.

Acknowledgments

The research was financially supported by the IGA FA MENDELU No. TP 5/2017.

\section{REFERENCES}

ADAMCOVA, D., VAVERKOVA, M. D., BARTOŇ, S., HAVLÍČEK, Z. and BŘOUŠKOVÁ, E. 2016a. Soil contamination in landfills: a case study of a landfill in Czech Republic. Solid Earth, 7:239-247.

ADAMCOVÁ, D., VAVERKOVÁ, M. D. and BŘOUŠKOVÁ, E. 2016b. The toxicity of two types of sewage sludge form wastewater treatment plant for plants. J. Ecol. Eng., 17(2): 33-37.

ALKASSASBEH, J. Y. M., HENG, L. Y. and SURIF, S. 2009. Toxicity testing and the effect of landfill leachate in Malaysia on behavior of common carp (Cyprinus carpio L., 1758; pisces, Cyprinidae). Am. J. Environ. Sci., 5(3): 209-217. 
BADERNA, D., MAGGIONI, S., BORIANI, E., GEMMA, S., MOLTENI, M., LOMBARDO, A., COLOMBO, A., BORDONALI, S., ROTELLA, G., LODI, M., and BENFENATI. E. 2011. A combined approach to investigate the toxicity of an industrial landfill's leachate: chemical analyses, risk assessment and in vitro assays. Environ. Res., 111(4): 603-613.

BAUN, D. L. and CHRISTENSEN, T. H. 2004. Speciation of heavy metals in landfill leachate: a review. Waste Manage. Res., 22(1): 3-23.

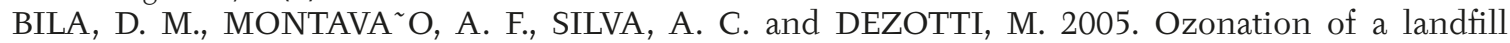
leachate: evaluation of toxicity removal and biodegradability improvement. J. Hazard. Mater., 117(2-3): 235-242.

BORTOLOTTO, T., BERTOLDO, J. B., DA SILVEIRA, F. Z., DEFAVERI, T. M., SILVANO, J. and PICH, C. T. 2009. Evaluation of the toxic and genotoxic potential of landfill leachates using bioassays. Environ. Toxicol. Pharmacol., 28(2): 288-293.

BUDI, S., SULIASIH, B. A., OTHMAN, M. S., HENG, L. Y. and SURIF, S. 2016. Toxicity identification evaluation of landfill leachate using fish, prawn and seed plant. Waste Manage., 55: 231-237.

FARGAŠOVÁ, A. 2004. Toxicity comparison of some possible toxic metals (Cd, Cu, Pb, Se, Zn) on young seedlings of Sinapis alba. Plant Soil Environ. 50:33-38.

GHOSH, P., THAKUR, I.S. and KAUSHIK, A. 2017. Bioassays for toxicological risk assessment of landfill leachate: A review. Eco. Environ. Safety., 141: 259-270.

GUO, J.-S., ABBAS, A. A., CHEN, Y.-P., LIU, Z.-P., FANG, F. and CHEN, P. 2010. Treatment of landfill leachate using a combined stripping, Fenton, SBR, and coagulation process. J. Hazard. Mater., 178(1-3): 699-705.

GWOREK, B., DMUCHOWSKI W., GOZDOWSKI, D., KODA, E., OSIECKA, R. and BORZYSZKOWSKI, J. 2015. Influence of a Municipal Waste Landfill on the Spatial Distribution of Mercury in the Environment. PLOS ONE, 10(7): e0133130.

HU, L., DU, Y. and LONG, Y. 2017. Relationship between $\mathrm{H}_{2} \mathrm{~S}$ emissions and the migration of sulfurcontaining compounds in landfill sites. Ecol. Eng., 106: 17-23.

ISIDORI, M., LAVORGNA, M., NARDELLI, A. and PARRELLA, A. 2003. Toxicity identification evaluation of leachates from municipal solid waste landfills: a multispecies approach. J. Chemosphere., 52(1): 85-94.

KALČÍKOVÁ, G., BABIČ, J., PAVKO, A. and ŽGAJNAR GOTVAJN, A. 2014. Fungal and enzymatic treatment of mature municipal landfill leachate. Waste Manage., 34(4): 798-803.

KALCIKOVA, G., VAVROVA, M., ZAGORC-KONCAN, Z. and GOTVAJN A. Z. 2011. Seasonal variations in municipal landfill leachate quality. Manage Environ Q: Int. J., 22(5): 612-619.

KJELDSEN, P., BARLAZ, M. A., ROOKER, A. P., BAUN, A., LEDIN, A., and CHRISTENSEN, T. H. 2002. Present and long-term composition of MSW landfill leachate: a review. Crit. Rev. Env. Sci. Technol., 32(4): 297-336.

KODA, E., OSINSKI, P., SIECZKA, A. And WYCHOWANIAK, D. 2015. Areal Distribution of Ammonium Contamination of Soil-Water Environment in the Vicinity of Old Municipal Landfill Site with Vertical Barrier. Water., 7(6): 2656-2672.

KULIKOWSKA, D. and KLIMIUK, E. 2008. The effect of landfill age on municipal leachate composition. Bioresour. Technol., 99(13): 5981-5985.

KURNIAWAN, T. A., LO, W.-H. and CHAN, G. Y. S. 2006. Degradation of recalcitrant compounds from stabilized landfill leachate using a combination of ozone-GAC adsorption treatment. J. Hazard. Mater., 137(1): 433-455.

LAITINEN, N., LUONSI, A. and VILEN, J. 2006. Landfill leachate treatment with sequencing batch reactor and membrane bioreactor. Desalination, 191: 86-91.

LI, G., CHEN, J., YAN, W. and SANG, N. 2017. A comparison of the toxicity of landfill leachate exposure at the seed soaking and germination stages on Zea mays L. (maize). J. Environ. Sci., 55: 206-213.

LI, G.K., YUN, Y. and SANG, N. 2008. Effect of landfill leachate on cell cycle, micronucleus, and sister chromatid exchange in Triticum aestivum. J. Hazard. Mater., 155: 10-16.

LIANG, J., ZHANG, J. and WONG, M. H. 1999. Landfill Leachate Used as Irrigation Water on Landfill Sites during Dry Seasons. In: WONG, M. H., WONG, J. W. C. and BAKER, A. J. M. (Eds.). Remediation and Management of Degraded Lands. Boca Raton: Lewis Publisheres, pp. 305-317.

MENSER, H.A. 1981. Irrigation with landfill leachate. Biocycle, 22: 39-41.

MENSER, H. A., WINANT, W. A. and BENNETT O. L. 1983. Spray irrigation with landfill leachate. Biocycle, 24(3): 22-25.

OKA, A, D., FUJII, M., SODA, Y., ISHIGAKI, S., MACHIMURA, T. and IKE, M. 2017. Removal of heavy metals from synthetic landfill leachate in lab-scale vertical flow constructed wetlands. Sci. Total Environ. 584585: 742-750.

ÖMAN, C. B. and JUNESTEDT, C. 2008. Chemical characterization of landfill leachates - 400 parameters and compounds. Waste Manage., 28(10): 1876-1891.

PANDARD, P., DEVILlERS, J., CHARISSOU, A.-M., POULSEN, V., JOURDAIN, M.J., FERARD, J.-F., GRAND, C. and BISPO A. 2006. Selecting a battery of bioassays for ecological characterization of wastes. Sci. Total Environ., 363(1-3): 114-125. 
RENOU, S., GIVAUDAN, J. G., POULAIN, S., DIRASSOUYAN, F. and MOULIN, P. 2008. Landfill leachate treatment: review and opportunity. J. Hazard. Mater., 150(3): 468-493.

SANG, N. and LI, G.K. 2004. Genotoxicity of municipal landfill leachate on root tips of Vicia faba. Mutation Research/Genetic Toxicology and Environmental Mutagenesis, 560(2): 159-165.

SANG, N., LI, G. K. and XIN X. Y. 2006. Municipal landfill leachate induces cytogenetic damage in root tips of Hordeum vulgare. Ecotoxicol. Environ. Saf., 63(3): 469-73.

SILVA, A. C., DEZOTTI, M. and SANT'ANNA JR., G. L. 2004. Treatment and detoxification of a sanitary landfill leachate. J. Chemosphere., 55(2): 207-214.

TSARPALI, V., KAMILARI, M. and DAILIANIS, S. 2012. Seasonal alterations of landfill leachate composition and toxic potency in semi-arid regions. J. Hazard. Mater., 233-234: 163-171.

VAVERKOVÁ, M. D. and ADAMCOVÁ, D. 2014. Heavy Metals Uptake by Select Plant Species in the Landfill Area of Štěpánovice, Czech Republic. Pol. J. Environ. Stud., 23(6): 2265-2269.

VAVERKOVÁ, M. D., ADAMCOVÁ, D., and TOMAN, F. 2013. Verification of the occurrence of some plant species as indicators of landfill impact on the environment. Acta Univ. Agric. Silvic. Mendelianae Brun., 61(5): 1441-1450.

VAVERKOVÁ, M. D., ADAMCOVÁ, D., RADZIEMSKA, M., VOBĚRKOVÁ, S., MAZUR, Z. and ZLOCH, J. 2017. Assessment and evaluation of heavy metals removal from landfill leachate by Pleurotus ostreatus. Waste Biomass Valor., In press.

VAVERKOVÁ, M. D., TOMAN, F. and KOTOVICOVÁ, J. 2012. Research into the Occurrence of Some Plant Species as Indicators of Landfill Impact on the Environment. Pol. J. Environ. Stud., 21(3): 755-762.

VOBĚRKOVÁ, S., VAVERKOVÁ, M. D., BUREŠOVÁ, A., ADAMCOVÁ, D., VRŠANSKÁ, M., KYNICKÝ, J., BRTNICKÝ, M. and ADAM, V. 2017. Effect of inoculation with white-rot fungi and fungal consortium on the composting efficiency of municipal solid waste. Waste Manage., 61: 157-164.

WU, J. J., WU, C-C., MA, H.-W. and CHANG, C-C. 2004. Treatment of landfill leachate by ozone-based advanced oxidation processes. Chemosphere, 54(7): 997-1003.

ZHANG, Q. Q., TIAN, B. H., ZHANG, X., GHULAM, A., FANG, C. R. and HE, R. 2013. Investigation on characteristics of leachate and concentrated leachate in three landfill leachate treatment plants. Waste Manage., 33(11): 2277-2286.

ZHAO, R., XI, B., LIU, Y., SU, J. and LIU, S. 2017. Economic potential of leachate evaporation by using landfill gas: A system dynamics approach. Res. Cons. Rec., 124: 74-84.

Magdalena Daria Vaverková: magda.vaverkova@uake.cz

Jan Zloch:xzloch@mendelu.cz

Dana Adamcová: dana.adamcova@mendelu.cz

Maja Radziemska: maja_radziemska@sggw.pl

Tomáš Vyhnánek: tomas.vyhnanek@mendelu.cz

Václav Trojan: vaclav.trojan@mendelu.cz

Biljana Đorđević: biljana.dordevic@mendelu.cz

Martin Brtnický: martin.brtnicky@mendelu.cz 